\title{
Energy, Exergy Analysis, and Optimizations of Collector Cover Thickness of a Solar Still in El Oued Climate, Algeria
}

\author{
Abderrahmane Khechekhouche, ${ }^{1}$ A. Muthu Manokar, ${ }^{2}$ Ravishankar Sathyamurthy ${ }^{1 D},{ }^{3}$ \\ Fadl A. Essa, ${ }^{4}$ Milad Sadeghzadeh $\mathbb{1 0},{ }^{5}$ and Alibek Issakhov ${ }^{6}$ \\ ${ }^{1}$ Faculty of Technology, El Oued University, Algeria \\ ${ }^{2}$ Department of Mechanical Engineering, B.S. Abdur Rahman Crescent Institute of Science and Technology, Chennai 600 048, India \\ ${ }^{3}$ Department of Mechanical Engineering, KPR Institute of Engineering and Technology, Arasur, Coimbatore, \\ 641407 Tamil Nadu, India \\ ${ }^{4}$ Mechanical Engineering Department, Faculty of Engineering, Kafrelsheikh University, Kafrelsheikh, Egypt \\ ${ }^{5}$ Department of Renewable Energies and Environment, Faculty of New Sciences \& Technologies, University of Tehran, Tehran, Iran \\ ${ }^{6}$ Faculty of Mechanics and Mathematics, Department of Mathematical and Computer Modelling, Al-Farabi Kazakh \\ National University, Almaty, Kazakhstan
}

Correspondence should be addressed to Milad Sadeghzadeh; milad.sadeghzadeh@gmail.com

Received 29 November 2020; Accepted 28 February 2021; Published 13 March 2021

Academic Editor: Hafiz Muhammad Ali

Copyright (c) 2021 Abderrahmane Khechekhouche et al. This is an open access article distributed under the Creative Commons Attribution License, which permits unrestricted use, distribution, and reproduction in any medium, provided the original work is properly cited.

\begin{abstract}
Researches in many laboratories on solar still desalination are concerned with increasing efficiency using only solar energy. One of the techniques is the difference in the thickness of the glass cover of the distiller. In order to see the influence of this parameter on efficiency, three similar stills with three different glass coverings were investigated. The flow of heat goes through the cover, and higher glass temperature leads to solar still productivity becoming lower. This paper presents an optimization of glass thickness $\left(\mathrm{G}_{\mathrm{t}}\right)$ of a conventional solar still (CSS) in El Oued climate, Algeria. Based on the experimental results, the distilled water production rate, energy, and energy efficiency of the CSS have been discussed. The results showed that the suitable $G_{t}$ of the CSS was $3 \mathrm{~mm}$. The distilled water of around 3.15, 2.02, and $1.13 \mathrm{~kg}$ was produced by the CSS at energy efficiency of 30.71 , 19.02 , and $11.44 \%$ with the $G_{t}$ of 3,5 , and $6 \mathrm{~mm}$, respectively. The daily average exergy efficiency of $2.46,1.38$, and $0.84 \%$ was calculated for the CSS at $\mathrm{G}_{\mathrm{t}}$ of 3,5 , and $6 \mathrm{~mm}$, respectively.
\end{abstract}

\section{Introduction}

Solar distillation is one of the simplest, economical, and environmental solutions with no emission of toxic or dangerous gas [1-3]. This technique is used in many countries around the world, especially in the isolated areas. As its name indicates, it is based on solar energy which is renewable and free energy [4-7]. The solar distiller works according to the laws of heat and mass transfer [8]. Improving the productivity of pure water from a conventional solar distiller is the subject of research in several laboratories $[9,10]$. This improvement is based on two main parameters, solar radiation and the gradient of temperature between water and glazing. In addition, exergy, energy, and technoeconomic assessments have been widely carried out to monitor the performance of solarbased conversion systems such as solar distillers to demonstrate their feasibility [11-18]. To prove the first parameter, an experiment was performed in the summer season and in the winter season to see the effect of solar radiation on traditional distillation production; the results show $89.44 \%$ increase in productivity during the summer season [19]. Another experiment used reflectors to focus the solar radiation that passes through the still's glass; the rate of improvement was approximately $30 \%$ [20].

The lenses were also used to increase a traditional solar still's performance, and the result obtained was 638\% [21]. 
To prove the second parameter, double glazing was used in a solar still to reduce temperature gradient, and the results show $55.7 \%$ reduction in productivity [22]. There have also been many studies on the glazing itself, for example, a study which tested the cooling of glass evaluated the productivity of the solar stills. The experimental results revealed that the pure water productivity is $10.06 \mathrm{~L} / \mathrm{m}^{2}$.day [23]. Another study shows that efficiency of solar distiller glass with water cooling was $11.81 \%$ more efficient than the solar still without water cooling [24].

According to an experimental study, cooling of glass covers can also be achieved by flowing air over the glass cover [25]. The use of partial shading on a CSS gave $12 \%$ improvement in productivity, a result confirmed by an experimental study carried out in southern Algeria [26]. Some researchers have tried to adjust the glazing angle to maximize pure water production; they have found that the best angles vary between $20^{\circ}$ and $30^{\circ}$. The best glazing angle was $30^{\circ}$ with an output of $3517 \mathrm{~kg} / \mathrm{m}^{2}$ in the autumn season and $3633 \mathrm{~kg} / \mathrm{m}^{2}$ in the winter; the best inclination was $20^{\circ}$ with a yield of $5224 \mathrm{~kg} / \mathrm{m}^{2}$ in the spring season and $4527 \mathrm{~kg} / \mathrm{m}^{2}$ in the summer season [27].

The variation of 3 different glazing thicknesses $(4,6$, and $8 \mathrm{~mm}$ ) was published by Panchal and Shah [28]. The outcome of the study indicates that the best pure water production corresponds to the $4 \mathrm{~mm}$ thickness. The results of an experiment revealed that while the thickness of the glass cover of a solar still reduces to $3.5 \mathrm{~mm}$, the average output of pure water from the still was $31.13 \%$ higher than that from a solar still with a $4 \mathrm{~mm}$ thick glass cover [29]. Several experiments were reported on the effect of different glass covers thickness on a solar still performance [30-32].

A theoretical and experimental study was done on three different cover thicknesses to determine the optimum thickness of the solar still glass cover. The results obtained show that a glass cover thickness of $4 \mathrm{~mm}$ and $5 \mathrm{~mm}$ has 27 and $12 \%$ higher production as compared to a thickness of $6 \mathrm{~mm}$ [33]. Two solar stills with two glass lids with different thicknesses of $4 \mathrm{~mm}$ and $6 \mathrm{~mm}$ were tested; the best productivity of 1.60 liters from the still with the $4 \mathrm{~mm}$ glazing and 1.55 liters from the still with the $6 \mathrm{~mm}$ glazing was reported [34, 35]. The heat flow through the glass of a CSS has been studied recently [36]. In another study, 5 glass covers were tested (2, $6,10,14$, and $18 \mathrm{~mm}$ ); the result indicates that optimum thickness that offers the highest pure water productivity is $6 \mathrm{~mm}$ [37]. The influence of a large glazing thickness on the performance of a solar still was studied by Khechekhouche et al. [38]. The cover consists of two $3 \mathrm{~mm}$ thick glass plates separated by a $100 \mathrm{~mm}$ air layer, forming an air chamber isolated from the sides. The results show that this technique minimizes the efficiency of the distiller by $56.52 \%$ compared to the CSS [38].

From the detailed literature, it has been identified that only few works have been reported on the effect of glass thickness on energy and exergy efficiencies of a solar still. Hence, the present work consists of making an experiment with three conventional solar stills, and each still has a glazing with a thickness that differs from the other distillers for the climatic condition of the El Oued climate, Algeria. The
TABLE 1: Meteorological conditions.

\begin{tabular}{lc}
\hline Sun lever & $5: 41$ \\
Sunset & $19: 19$ \\
Ambient temperature & $35\left({ }^{\circ} \mathrm{C}\right)$ \\
Humidity & $25 \%$ \\
\hline
\end{tabular}

objective is to optimize the thickness in order to obtain the best productivity in pure water. In this work, calculation of energy, exergy efficiency, and fractional exergy of evaporation and convection between $T_{\text {s.w }}$ and $T_{\text {c.c }}$ is a novelty of the present study.

\section{Experimental Set-Up and Methodology}

2.1. Protocol of the Experiment. The city of El Oued southeast of Algeria's geographical coordinates is $33.3676^{\circ}$ north latitude and $6.8516^{\circ}$ longitude. The experiment was carried out several times, and since the results obtained are the same, one sunny day (25 $5^{\text {th }}$ May 2018) was considered. K-1-type thermocouples were placed on solar stills and precisely in the water, below and above the glass cover, and in the open place to measure the ambient temperature. The glass side of the two stills faces south for maximum exposure to solar radiation. The quantities of distilled water produced were measured manually every hour by a graduated cup. Temperatures were measured every hour from 9:00 AM to 4:00 PM. The meteorological condition of the experimental day is shown in Table 1.

2.2. Solar Distiller Description. Figure 1 shows the schematic of the CSS with location of thermocouples. This system helps to purify polluted water and restore it to pure water. It is a very simple technique which uses energy from solar radiation. Nevertheless, this type of system is distinguished from other desalination devices by its relatively low efficiency. This distiller has a very simple construction with a low investment cost. The distiller used in our experiment consists basically of a square wooden box of $0.5 \times 0.5 \mathrm{~m}$, a transparent glass cover of $0.55 \times 0.55 \mathrm{~m}$, a thickness of $0.003 \mathrm{~m}$, a PVC recovery tube of $0.60 \mathrm{~m}$ in length and $0.025 \mathrm{~m}$ in diameter situated in the lower part of the distillery, and finally a pure-water storage tank.

2.3. Treatment Data. The experiment was performed in the climate of El Oued region, in southeast Algeria, on $25^{\text {th }}$ May 2018. Three separate solar stills have the same size with the same inclination angle $\left(20^{\circ}\right.$ with the horizontal). At the same time, all the three distillers (CSS with the $G_{t}$ of 3, 5, and $6 \mathrm{~mm}$ ) are exposed to the sun on the same experiential day with similar water quality and quantity. Each distiller has a thickness covering that differs from other distillers as shown in Figure 2.

\section{Results and Discussion}

3.1. Hourly Variations of Solar Intensity and Ambient Temperature. Figure 3 shows the hourly variations of solar 


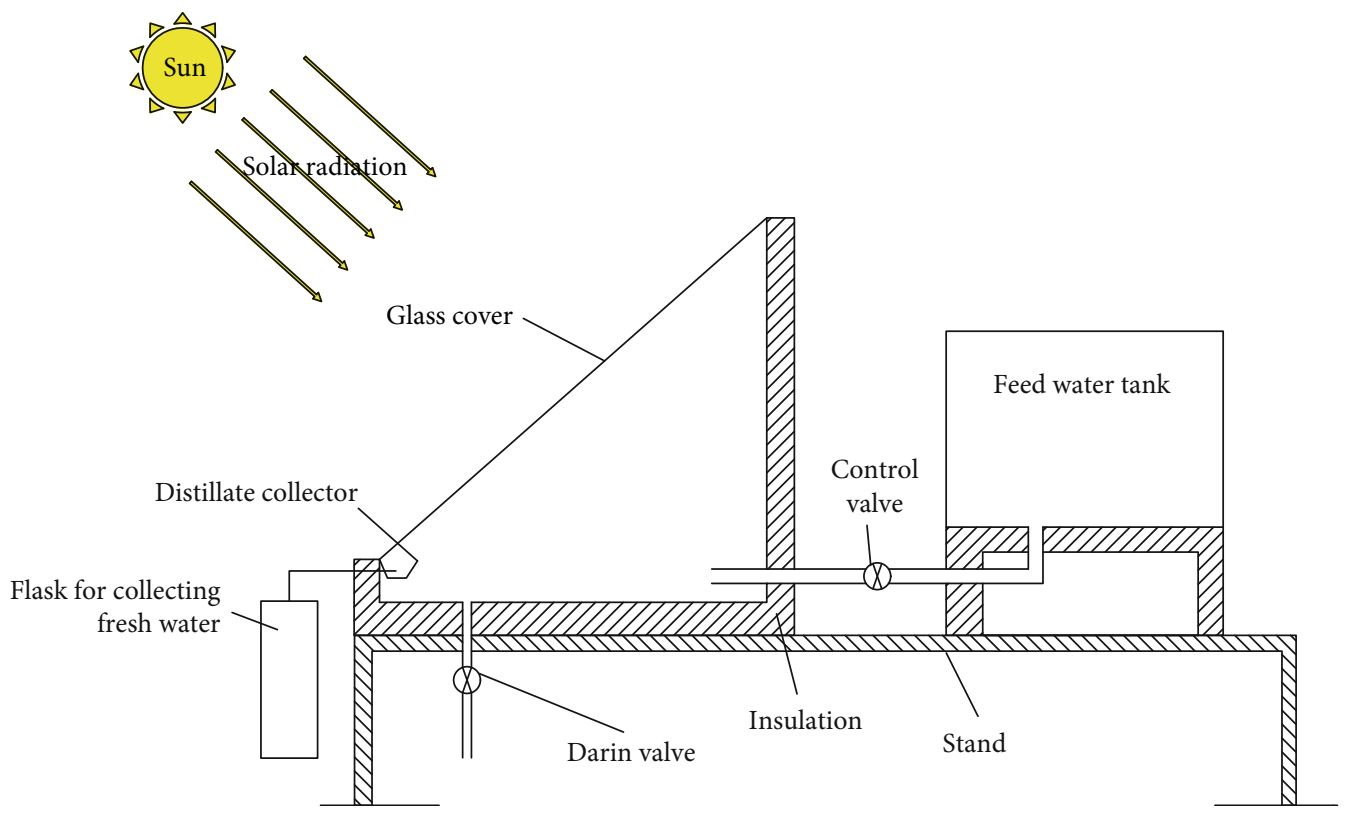

FIGURE 1: Location of the thermocouples.

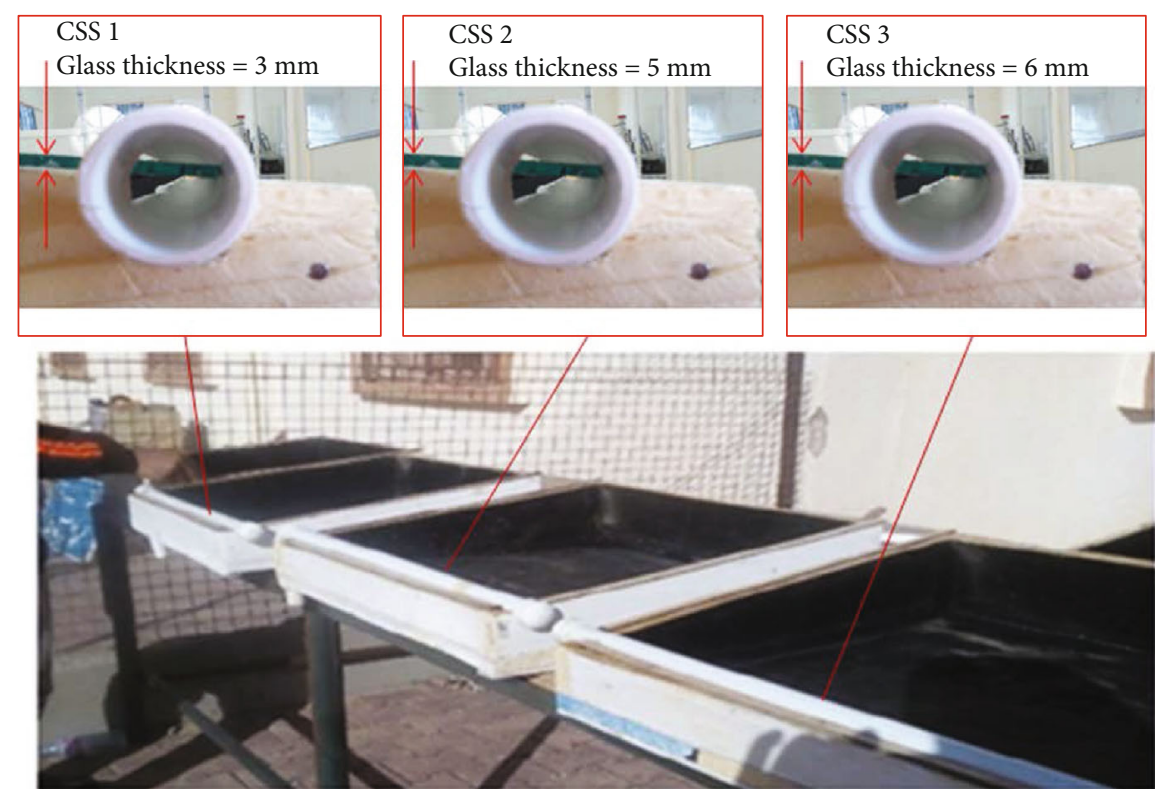

FIgURE 2: Photographic view of the experimental set-up.

intensity and ambient temperature. From the graph, it is clear that both the values increase linearly and reached the maximum value at $1 \mathrm{PM}$, and after $1 \mathrm{PM}$, it has decreased. The maximum solar intensity and an ambient temperature of $1005 \mathrm{~W} / \mathrm{m}^{2}$ and $36^{\circ} \mathrm{C}$ has been recorded. The daily average solar intensity and ambient temperature during the testing have been recorded as $754.38 \mathrm{~W} / \mathrm{m}^{2}$ and $32.25^{\circ} \mathrm{C}$, respectively. During the testing, the sky was very clear and there were no clouds.

3.2. Hourly Variations of Water Temperature. Figure 4 shows the hourly variations of water temperature $\left(T_{\mathrm{W}}\right)$ for the
CSS at $\mathrm{G}_{\mathrm{t}}$ of 3,5 , and $6 \mathrm{~mm}$. $T_{\mathrm{W}}$ has a similar curve like solar intensity and ambient temperature since the water temperature is directly proportional to the solar intensity. The maximum $T_{\mathrm{W}}$ of 60,58 , and $55^{\circ} \mathrm{C}$ has been recorded for the CSS at $\mathrm{G}_{\mathrm{t}}$ of 3,5 , and $6 \mathrm{~mm}$, respectively. The daily average $T_{\mathrm{W}}$ of $49.5,47.88$, and $46^{\circ} \mathrm{C}$ has been calculated for the CSS at $G_{t}$ of 3,5 , and $6 \mathrm{~mm}$, respectively. From the experimentation of the CSS at different $G_{t}$, the maximum $T_{\mathrm{W}}$ obtained for the $\mathrm{G}_{\mathrm{t}}$ of $3 \mathrm{~mm}$ is found. The CSS at $\mathrm{G}_{\mathrm{t}}$ of 5 and $6 \mathrm{~mm}$ reduces the daily average $T_{\mathrm{W}}$ by $3.28 \%$ and $7.07 \%$, respectively, as compared to the CSS at $G_{t}$ of $3 \mathrm{~mm}$. Compared to the other two stills, 


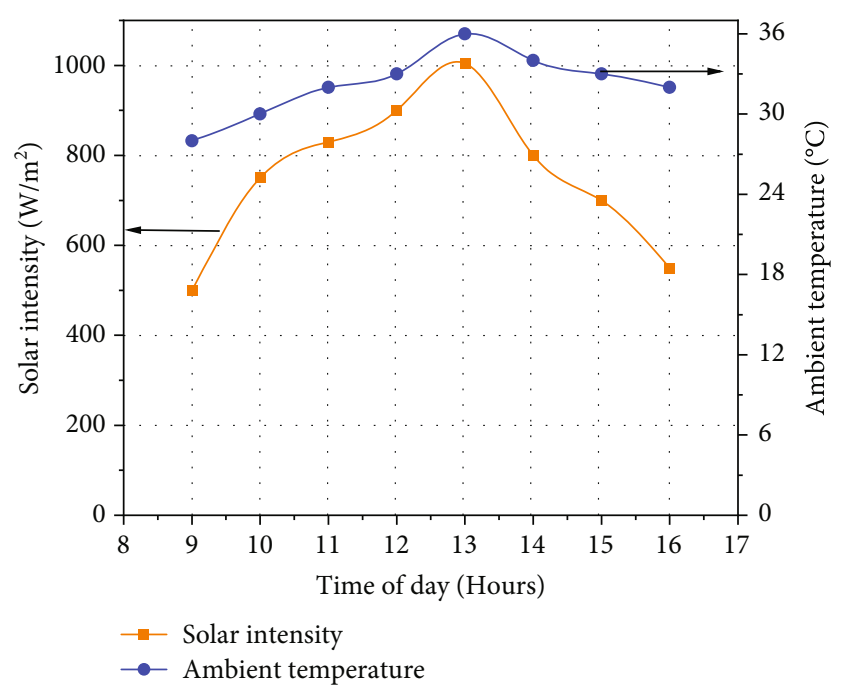

Figure 3: Time-wise fluctuation of solar intensity and ambient temperature.

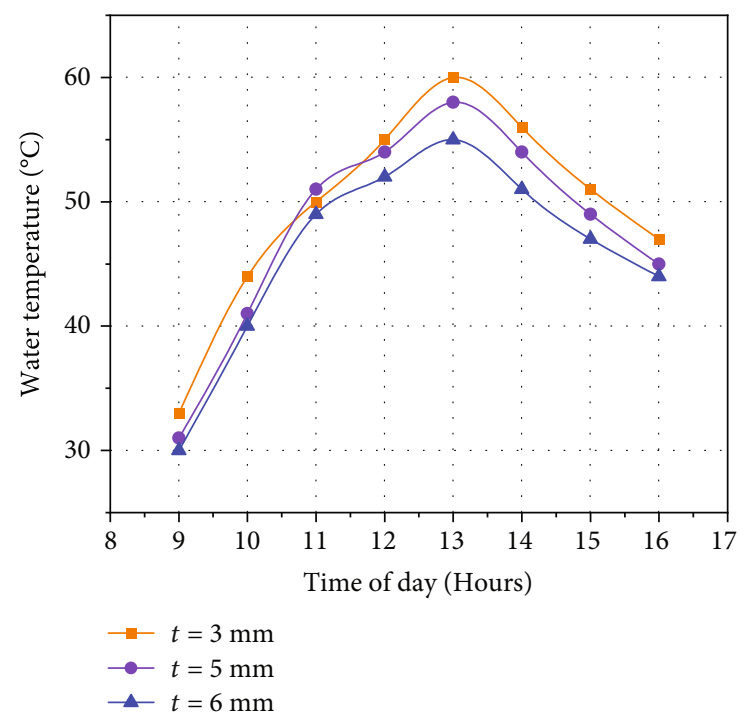

Figure 4: Time-wise fluctuation of $T_{\mathrm{W}}$.

the water temperature in the CSS at $\mathrm{G}_{\mathrm{t}}$ of $3 \mathrm{~mm}$ is highest, and it is known that any rise in the water temperature causes an increase in evaporation.

3.3. Hourly Variations of Glass Temperature. Figure 5 shows the hourly variations of glass temperature $\left(T_{\mathrm{G}}\right)$ for the CSS at $\mathrm{G}_{\mathrm{t}}$ of 3,5 , and $6 \mathrm{~mm}$. $T_{\mathrm{G}}$ also has a similar curve like solar intensity. The maximum $T_{\mathrm{G}}$ of 49,51 , and $54^{\circ} \mathrm{C}$ has been recorded for the CSS at $\mathrm{G}_{\mathrm{t}}$ of 3,5 , and $6 \mathrm{~mm}$, respectively. The daily average $T_{\mathrm{G}}$ of $42.25,44.25$, and $46.13^{\circ} \mathrm{C}$ has been calculated for the CSS at $\mathrm{G}_{\mathrm{t}}$ of 3,5 , and $6 \mathrm{~mm}$, respectively. From the experimentation of the CSS at different $G_{t}$, it is found that the CSS at $\mathrm{G}_{t}$ of $3 \mathrm{~mm}$ has minimum $T_{\mathrm{G}}$ as compared to the CSS at $\mathrm{G}_{\mathrm{t}}$ of 5 and $6 \mathrm{~mm}$. The CSS at $\mathrm{G}_{\mathrm{t}}$ of 5 and $6 \mathrm{~mm}$ increases the daily average $T_{\mathrm{G}}$ by $4.52 \%$ and $8.4 \%$, respectively, as compared to the CSS at the $\mathrm{G}_{t}$ of $3 \mathrm{~mm}$. From graphs 3 and 4 , it is found that the CSS at $G_{t}$ of $3 \mathrm{~mm}$ has the

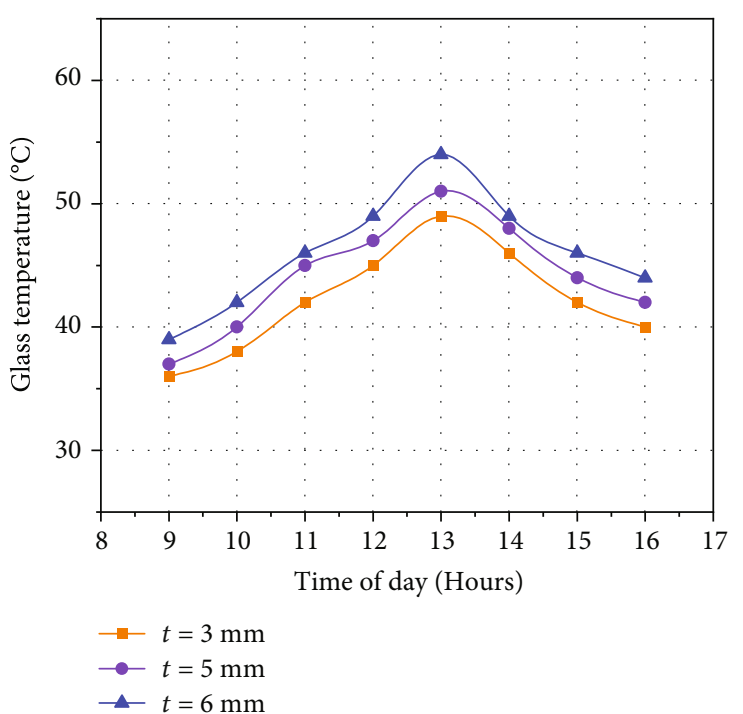

Figure 5: Time-wise fluctuation of $T_{\mathrm{G}}$.

maximum $T_{\mathrm{W}}$ and minimum $T_{\mathrm{G}}$ which produces the higher difference between $T_{\mathrm{W}}$ and $T_{\mathrm{G}}$.

3.4. Hourly Variations of the Yield. The value of EHTC is directly proportional to the $T_{\mathrm{W}}$ so it has a similar curve like a $T_{\mathrm{W}}$ curve. The maximum EHTC of $46.28,37$, and $28.34 \mathrm{~W} / \mathrm{m}^{2} \mathrm{k}$ have been recorded for the CSS at $\mathrm{G}_{\mathrm{t}}$ of 3,5 , and $6 \mathrm{~mm}$, respectively. The daily average EHTC of 26.71, 18.76 , and $9.81 \mathrm{~W} / \mathrm{m}^{2} \mathrm{k}$ have been calculated for the CSS at $\mathrm{G}_{\mathrm{t}}$ of 3,5 , and $6 \mathrm{~mm}$, respectively. The CSS at $\mathrm{G}_{t}$ of 5 and $6 \mathrm{~mm}$ reduces the daily average EHTC by $29.74 \%$ and $63.27 \%$, respectively, as compared to the CSS at $G_{t}$ of $3 \mathrm{~mm}$. Figure 6 shows the hourly variations of the yield produced from the CSS at $\mathrm{G}_{\mathrm{t}}$ of 3,5 , and $6 \mathrm{~mm}$. The yield produced from the CSS at difference $G_{t}$ has a similar curve like the EHTC because yield is directly proportional to the EHTC. The maximum hourly yield produced from the CSS at $\mathrm{G}_{t}$ of 3,5 , and $6 \mathrm{~mm}$ is $0.76,0.45$, and $0.31 \mathrm{~kg}$, respectively. The daily average yield produced from the CSS at $\mathrm{G}_{\mathrm{t}}$ of 3,5 , and $6 \mathrm{~mm}$ is $3.15,1.9$, and $1.1 \mathrm{~kg}$, respectively. The CSS at $\mathrm{G}_{\mathrm{t}}$ of 5 and $6 \mathrm{~mm}$ reduces the daily yield by $40.48 \%$ and $65.15 \%$, respectively, as compared to the CSS at $\mathrm{G}_{\mathrm{t}}$ of $3 \mathrm{~mm}$. From the yield production, it is clear that the CSS at $G_{t}$ of $3 \mathrm{~mm}$ has maximum yield because of the higher difference between $T_{\mathrm{W}}$ and $T_{\mathrm{G}}$. This difference between $T_{\mathrm{W}}$ and $T_{\mathrm{G}}$ is called the gradient of temperature. Due to higher temperature difference; the CSS at Gt of $3 \mathrm{~mm}$ produced more yield than the CSS at Gt of 5 and $6 \mathrm{~mm}$.

3.5. Thermal Efficiency. Figure 7 shows the thermal efficiency of the CSS at $\mathrm{G}_{\mathrm{t}}$ of 3,5 , and $6 \mathrm{~mm}$. The thermal efficiency of the CSS at different $G_{t}$ has the similar curve like the yield. The maximum thermal efficiency of the CSS at $G_{t}$ of 3,5 , and $6 \mathrm{~mm}$ is $47.33,32.86$, and $23.87 \%$, respectively. The daily average thermal efficiency of the CSS at $G_{t}$ of 3, 5, and $6 \mathrm{~mm}$ is $30.71,18.35$, and $11.25 \%$, respectively. The CSS at $\mathrm{G}_{\mathrm{t}}$ of 5 and $6 \mathrm{~mm}$ reduces the daily average thermal efficiency by $40.25 \%$ and $63.37 \%$ as compared to the CSS at $G_{t}$ of $3 \mathrm{~mm}$. 


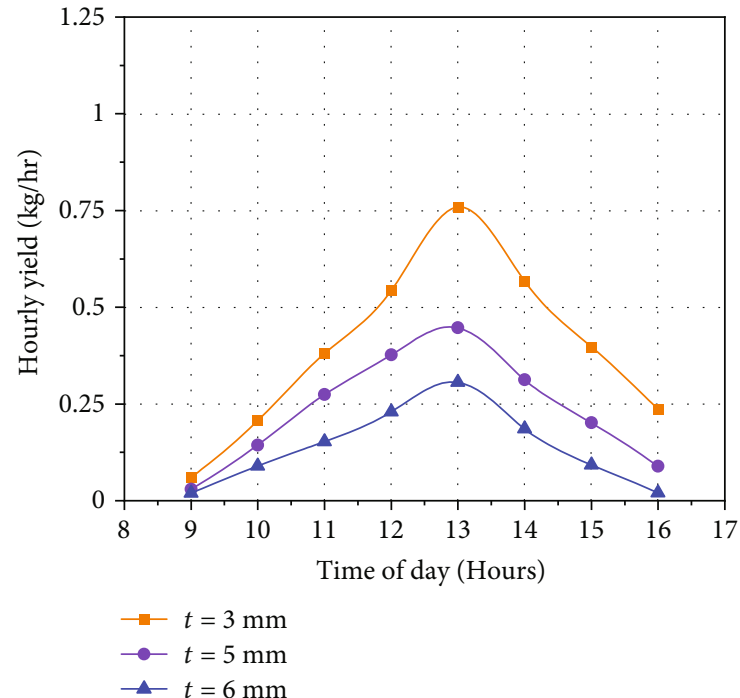

FIgUre 6: Time-wise fluctuation of yield.

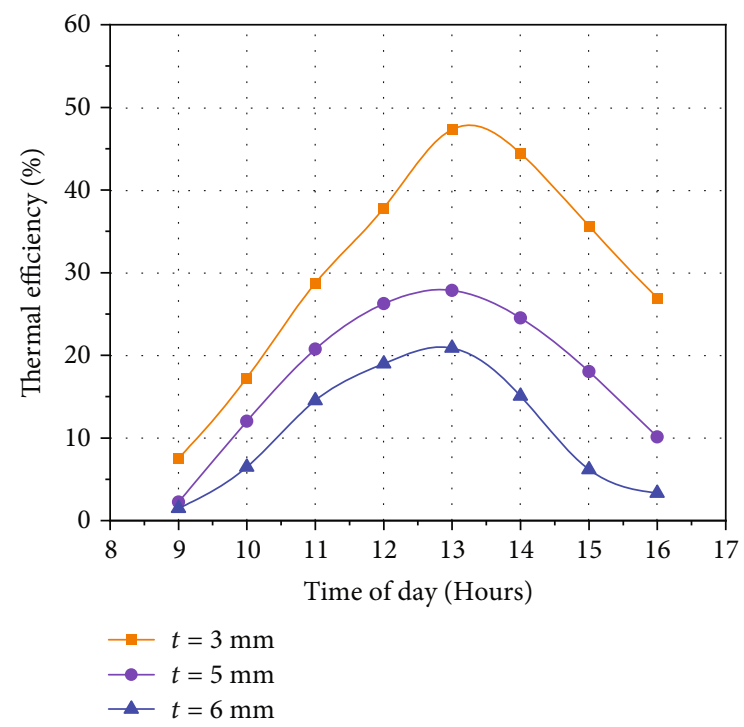

Figure 7: Time-wise fluctuation of thermal efficiency.

The thermal efficiency of the system mostly depends on the yield produced from the CSS. In this experiment, the yield produced from the CSS is maximum in the case of $G_{t}$ of $3 \mathrm{~mm}$, so thermal efficiency of the system is higher in the case of $\mathrm{G}_{\mathrm{t}}$ of $3 \mathrm{~mm}$.

The thermal efficiency of the CSS is given by [23-25]

$$
\eta_{\text {passive }}=\frac{\sum \dot{m}_{e w} L}{\sum I(t) A_{s} \times 3600} \times 100 \text {. }
$$

3.6. Exergy Efficiency. Figure 8 shows the exergy efficiency of the CSS at $\mathrm{G}_{\mathrm{t}}$ of 3,5 , and $6 \mathrm{~mm}$. The exergy efficiency of the CSS at different $\mathrm{G}_{\mathrm{t}}$ has the similar curve like the thermal efficiency. The maximum hourly exergy efficiency of the CSS at $\mathrm{G}_{\mathrm{t}}$ of 3,5 , and $6 \mathrm{~mm}$ is $4.72,2.62$, and $1.93 \%$, respectively. The daily average exergy efficiency of the CSS at $G_{t}$ of 3,5 ,

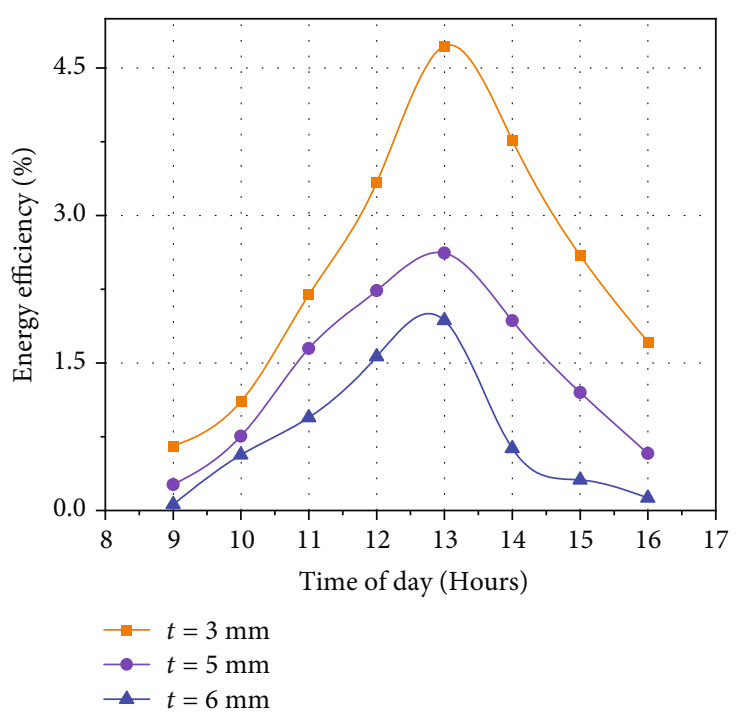

Figure 8: Time-wise fluctuation of exergy efficiency.

and $6 \mathrm{~mm}$ is $2.46,1.38$, and $0.84 \%$, respectively. The CSS at $\mathrm{G}_{\mathrm{t}}$ of 5 and $6 \mathrm{~mm}$ reduces the daily average exergy efficiency by $44.01 \%$ and $65.81 \%$, respectively, as compared to the CSS at $G_{t}$ of $3 \mathrm{~mm}$. The exergy efficiency of the system mostly depends on the yield produced from the CSS. In this research, the maximum exergy efficiency was calculated for the CSS at $G_{t}$ of $3 \mathrm{~mm}$. The performance of the CSS at $G_{t}$ of $3 \mathrm{~mm}$ is higher, so exergy efficiency is higher at the CSS at $G_{t}$ of $3 \mathrm{~mm}$.

The time-wise fractional exergy of evaporation and convection between $T_{\text {s.w }}$ and $T_{\text {c.c }}$ for the CSS at $G_{t}$ of 3 , 5 , and $6 \mathrm{~mm}$ is calculated using equations (10) and (11). It is found that fractional exergy of evaporation of the CSS at $G_{t}$ of $3 \mathrm{~mm}$ is higher than that of the CSS at $G_{t}$ of 5 and $6 \mathrm{~mm}$. The maximum hourly fractional exergy of evaporation of $96.1,96$, and $95.9 \%$ has been calculated for the CSS at $G_{t}$ of 3,5 , and $6 \mathrm{~mm}$, respectively. During the experimentation, it is found that the evaporation rate and water temperature of the CSS at $G_{t}$ of $3 \mathrm{~mm}$ are higher as compared to those of the CSS at $G_{t}$ of 5 and $6 \mathrm{~mm}$. So time-wise fractional exergy of evaporation of the CSS at $G_{t}$ of $3 \mathrm{~mm}$ is higher than that of CSS at $G_{t}$ of 5 and $6 \mathrm{~mm}$. It is also found that fractional exergy of convection of the CSS at $G_{t}$ of $5 \mathrm{~mm}$ is higher than that of the CSS at $G_{t}$ of 3 and $6 \mathrm{~mm}$. The maximum hourly fractional exergy of convection was calculated to be 9.4, 8.6 , and $8.4 \%$ for the CSS at $\mathrm{G}_{\mathrm{t}}$ of 3,5 , and $6 \mathrm{~mm}$, respectively. The reason for maximum fractional exergy of convection for the CSS at $G_{t}$ of $3 \mathrm{~mm}$ is the operating temperature of the $\mathrm{G}_{\mathrm{t}}$.

The EHTC starting from basin of the CSS to the glass cover is computed by [39-41]

$$
h_{e, w-g}=16.273 \times 10^{-3} \times h_{c, w-g}\left[\frac{P_{w}-P_{g i}}{T_{w}-T_{g i}}\right] \text {. }
$$


The convective heat transfer coefficient starting from the basin of the CSS to the glass cover is computed by $[39-41]$

$$
h_{c, w-g}=0.884\left[\left(T_{w}-T_{g i}\right)+\frac{\left(P_{w}-P_{g i}\right)\left(T_{w}+273\right)}{\left(268.9 \times 10^{-3}-P_{\mathrm{w}}\right)}\right] .
$$

Partial vapour pressure at the basin $T_{\mathrm{W}}$ is computed by [39-41]

$$
P_{w}=\exp \left(25.317-\frac{5144}{273+T_{w}}\right)
$$

Partial vapour pressure at the $T_{\mathrm{G}}$ is computed by [39-41]

$$
P_{g i}=\exp \left(25.317-\frac{5144}{273+T_{g i}}\right) \text {. }
$$

The thermal efficiency of the CSS is computed as [39-41]

$$
\eta_{\text {passive }}=\frac{\sum \dot{m}_{e w} L}{\sum I(t) A_{s} \times 3600} \times 100 .
$$

The exergy efficiency of the CSS is computed by [39-41]

$$
\eta_{\text {overall,exe }}=\frac{\sum E x_{\text {output }}}{\sum E x_{\text {input }}} .
$$

The hourly exergy output is computed by [39-41]

$$
\mathrm{Ex}_{\mathrm{output}}=\frac{m_{e w} L_{f g}}{3600} \times\left[1-\frac{T_{a}}{T_{w}}\right] .
$$

The hourly exergy input is computed by [39-41]

$$
\mathrm{Ex}_{\text {input }}=A_{w} I^{\prime}(t) \times\left[1-\frac{4}{3}\left(\frac{T_{a}}{T_{s}}\right)+\frac{1}{3}\left(\frac{T_{a}}{T_{s}}\right)^{4}\right] .
$$

The fractional exergies for evaporation and convection are calculated using equations (10) and (11) and are as follows [42]:

$$
\begin{gathered}
F_{e, b w-i g}=\frac{\mathrm{Ex}_{e, b w-i \mathrm{~g}}}{\mathrm{Ex}_{t i}}, \\
F_{c, b w-i g}=\frac{\mathrm{Ex}_{c, b w-i g}}{\mathrm{Ex}_{t i}} .
\end{gathered}
$$

3.7. Comparisons of Present Result and Similar Studies. Table 2 gives the several studies previously carried out

\begin{tabular}{|c|c|c|c|}
\hline Ref. no. & $\begin{array}{l}\text { Glass cover } \\
\text { thickness }\end{array}$ & $\begin{array}{l}\text { Energy } \\
\text { efficiency }\end{array}$ & $\begin{array}{c}\text { Exergy } \\
\text { efficiency }\end{array}$ \\
\hline \multirow{3}{*}[28]{} & $4 \mathrm{~mm}$ & - & - \\
\hline & $8 \mathrm{~mm}$ & - & - \\
\hline & $12 \mathrm{~mm}$ & - & - \\
\hline \multirow{2}{*}[29]{} & $3.5 \mathrm{~mm}$ & $21.42 \%$ & - \\
\hline & $4 \mathrm{~mm}$ & $28.09 \%$ & - \\
\hline \multirow{3}{*}[30]{} & $3.18 \mathrm{~mm}$ & $26.22 \%$ & - \\
\hline & $4.76 \mathrm{~mm}$ & $29.28 \%$ & - \\
\hline & $6.35 \mathrm{~mm}$ & $18.95 \%$ & \\
\hline \multirow{4}{*}[31]{} & $3 \mathrm{~mm}$ & $32-34 \%$ & - \\
\hline & $4 \mathrm{~mm}$ & $34-36 \%$ & \\
\hline & $5 \mathrm{~mm}$ & $30-32 \%$ & - \\
\hline & $6 \mathrm{~mm}$ & $26-28 \%$ & - \\
\hline \multirow{5}{*}[32]{} & $4 \mathrm{~mm}$ & & - \\
\hline & $8 \mathrm{~mm}$ & - & - \\
\hline & $>8 \mathrm{~mm}+$ air film & - & - \\
\hline & $12 \mathrm{~mm}$ & - & - \\
\hline & $>12 \mathrm{~mm}+$ air film & - & - \\
\hline \multirow{3}{*}[33]{} & $4 \mathrm{~mm}$ & $27 \%$ & - \\
\hline & $5 \mathrm{~mm}$ & $22 \%$ & - \\
\hline & $6 \mathrm{~mm}$ & $17 \%$ & - \\
\hline \multirow{7}{*}[34]{} & $2 \mathrm{~mm}$ & $45-50 \%$ & - \\
\hline & $3 \mathrm{~mm}$ & $40-45 \%$ & - \\
\hline & $4 \mathrm{~mm}$ & $30-35 \%$ & - \\
\hline & $5 \mathrm{~mm}$ & $30 \%$ & - \\
\hline & $6 \mathrm{~mm}$ & $25-30 \%$ & - \\
\hline & $7 \mathrm{~mm}$ & $20-25 \%$ & - \\
\hline & $8 \mathrm{~mm}$ & $15-20 \%$ & \\
\hline \multirow{2}{*}[35]{} & $4 \mathrm{~mm}$ & - & - \\
\hline & $6 \mathrm{~mm}$ & - & - \\
\hline \multirow{5}{*}[37]{} & $2 \mathrm{~mm}$ & - & - \\
\hline & $6 \mathrm{~mm}$ & - & - \\
\hline & $10 \mathrm{~mm}$ & - & - \\
\hline & $14 \mathrm{~mm}$ & - & - \\
\hline & $18 \mathrm{~mm}$ & - & - \\
\hline$[38]$ & $\begin{array}{c}4 \mathrm{~mm} \\
8 \mathrm{~mm}+\text { air film }\end{array}$ & $-52.7 \%$ & - \\
\hline \multirow{3}{*}{$\begin{array}{l}\text { Our current } \\
\text { work }\end{array}$} & $3 \mathrm{~mm}$ & $30.71 \%$ & $2.46 \%$ \\
\hline & $5 \mathrm{~mm}$ & $18.35 \%$ & $1.38 \%$ \\
\hline & $6 \mathrm{~mm}$ & $11.25 \%$ & $0.84 \%$ \\
\hline
\end{tabular}
by researchers on the thickness of the glass cover of solar stills. It also shows the results obtained on the productivity of pure water and the thermal efficiency of the stills tested, and it was noticed that energy efficiency varies between 17 and $42 \%$, and it is found that the present results vary between 11.25 and $30.71 \%$. We draw the attention that
TABLE 2: Summary of various researchers on the glass cover thickness.

some research does not calculate either energy efficiency or exergy efficiency. Comparing the efficiencies, it is found that the CSS with $3 \mathrm{~mm}$ gives a good value in both types of efficiencies [38]. 


\section{Conclusion}

Based on the investigational outcome on the CSS, the following conclusions are arrived at.

(i) The CSS at $G_{t}$ of 3, 5, and $6 \mathrm{~mm}$ has a yield of 3.15, 1.9 , and $1.1 \mathrm{~kg}$, respectively. The CSS at $\mathrm{G}_{\mathrm{t}}$ of $3 \mathrm{~mm}$ produced the $40.48 \%$ and $65.15 \%$ higher yield than the CSS at $\mathrm{G}_{\mathrm{t}}$ of 5 and $6 \mathrm{~mm}$, respectively.

(ii) The thermal and exergy efficiencies of 30.71, 18.35, and $11.25 \%$ and $2.46,1.38$, and $0.84 \%$ have been obtained for the CSS at $G_{t}$ of 3,5 , and $6 \mathrm{~mm}$, respectively.

(iii) The thermal efficiency of the CSS is higher in the case of CSS at $G_{t}$ of $3 \mathrm{~mm}$. The thermal efficiency of the CSS at $\mathrm{G}_{\mathrm{t}}$ of $3 \mathrm{~mm}$ is $40.25 \%$ and $63.37 \%$ higher as compared to that of the CSS at $G_{t}$ of 5 and $6 \mathrm{~mm}$, respectively.

(iv) The exergy efficiency of the CSS is higher in the case of CSS at $G_{t}$ of $3 \mathrm{~mm}$. The exergy efficiency of the CSS at $\mathrm{G}_{\mathrm{t}}$ of $3 \mathrm{~mm}$ is $44.01 \%$ and $65.81 \%$ higher as compared to that of the CSS at $\mathrm{G}_{\mathrm{t}}$ of 5 and $6 \mathrm{~mm}$, respectively.

\section{Nomenclature}

$\mathrm{G}_{\mathrm{t}}$ : $\quad$ Glass thickness

CSS: Conventional solar still

$T_{\mathrm{W}}$ : Water temperature

$T_{\mathrm{G}}$ : Glass temperature

EHTC: Evaporative heat transfer coefficient.

\section{Data Availability}

The data used to support the findings of this study are included within the article.

\section{Conflicts of Interest}

The authors declare that they have no conflicts of interest.

\section{References}

[1] M. H. Ahmadi, M. Ghazvini, M. Sadeghzadeh et al., "Solar power technology for electricity generation: a critical review," Energy Sci Eng, vol. 6, no. 5, pp. 340-361, 2018.

[2] A. Naseri, M. Bidi, and M. H. Ahmadi, "Thermodynamic and exergy analysis of a hydrogen and permeate water production process by a solar-driven transcritical $\mathrm{CO}_{2}$ power cycle with liquefied natural gas heat sink," Renewable Energy, vol. 113, pp. 1215-1228, 2017.

[3] A. Naseri, M. Bidi, M. H. Ahmadi, and R. Saidur, "Exergy analysis of a hydrogen and water production process by a solardriven transcritical $\mathrm{CO}_{2}$ power cycle with Stirling engine," Journal of Cleaner Production, vol. 158, pp. 165-181, 2017.

[4] A. Mohammadi, M. H. Ahmadi, M. Bidi, M. Ghazvini, and T. Ming, "Exergy and economic analyses of replacing feedwater heaters in a Rankine cycle with parabolic trough collectors," Energy Reports, vol. 4, pp. 243-251, 2018.
[5] M. Dehghani Madvar, M. Alhuyi Nazari, J. Tabe Arjmand, A. Aslani, R. Ghasempour, and M. H. Ahmadi, "Analysis of stakeholder roles and the challenges of solar energy utilization in Iran," International Journal of Low-Carbon Technologies, vol. 13, no. 4, pp. 438-451, 2018.

[6] A. Khatibi, F. Razi Astaraei, and M. H. Ahmadi, "Generation and combination of the solar cells: a current model review," Energy Sci Eng, vol. 7, no. 2, pp. 305-322, 2019.

[7] M. H. Ahmadi, A. Baghban, M. Sadeghzadeh et al., "Evaluation of electrical efficiency of photovoltaic thermal solar collector," Engineering Applications of Computational Fluid Mechanics, vol. 14, no. 1, pp. 545-565, 2020.

[8] A. Naeimi, M. H. Ahmadi, M. Sadeghzadeh, and A. Kasaeian, "Optimum arrangement of two-stage plug and concentrate recycling RO systems using thermodynamic and exergy analysis," International Journal of Numerical Methods for Heat of Fluid Flow, vol. 30, no. 6, pp. 3323-3348, 2019.

[9] S. W. Sharshir, N. Yang, G. Peng, and A. E. Kabeel, "Factors affecting solar stills productivity and improvement techniques: a detailed review," Applied Thermal Engineering, vol. 100, pp. 267-284, 2016.

[10] A. Muthu Manokar, D. Prince Winston, A. E. Kabeel, R. Sathyamurthy, and T. Arunkumar, "Different parameter and technique affecting the rate of evaporation on active solar still -a review," Heat and Mass Transfer, vol. 54, no. 3, pp. 593630, 2018

[11] M. Ashouri, M. H. Ahmadi, M. Feidt, and F. R. Astaraei, "Exergy and energy analysis of a regenerative organic Rankine cycle based on flat plate solar collectors," Mechanics \& Industry, vol. 18, no. 2, p. 217, 2017.

[12] M. Ashouri, A. M. Khoshkar Vandani, M. Mehrpooya, M. H. Ahmadi, and A. Abdollahpour, "Techno-economic assessment of a Kalina cycle driven by a parabolic trough solar collector," Energy Conversion and Management, vol. 105, pp. 1328-1339, 2015.

[13] B. Ghorbani, M. Mehrpooya, and M. Sadeghzadeh, "Developing a tri-generation system of power, heating, and freshwater (for an industrial town) by using solar flat plate collectors, multi-stage desalination unit, and Kalina power generation cycle," Energy Conversion and Management, vol. 165, pp. 113-126, 2018.

[14] B. Ghorbani, M. Miansari, S. Zendehboudi, and M.H. Hamedi, "Exergetic and economic evaluation of carbon dioxide liquefaction process in a hybridized system of water desalination, power generation, and liquefied natural gas regasification," Energy Conversion and Management, vol. 205, p. $112374,2020$.

[15] B. Ghorbani, R. Shirmohammadi, and M. Mehrpooya, "Development of an innovative cogeneration system for fresh water and power production by renewable energy using thermal energy storage system," Sustainable Energy Technologies and Assessments, vol. 37, 2020.

[16] B. Ghorbani, R. Shirmohammadi, M. Amidpour, F. Inzoli, and M. Rocco, "Design and thermoeconomic analysis of a multieffect desalination unit equipped with a cryogenic refrigeration system," Energy Conversion and Management, vol. 202, p. $112208,2019$.

[17] B. Ghorbani, M. Mehrpooya, and S. A. Mousavi, "Hybrid molten carbonate fuel cell power plant and multiple-effect desalination system," Journal of Cleaner Production, vol. 220, pp. 1039-1051, 2019. 
[18] M. S. Niasar, B. Ghorbani, M. Amidpour, and R. Hayati, "Developing a hybrid integrated structure of natural gas conversion to liquid fuels, absorption refrigeration cycle and multi effect desalination (exergy and economic analysis)," Energy, vol. 189, p. 116162, 2019.

[19] A. Khechekhouche, A. Boukhari, Z. Driss, and N. E. Benhissen, "Seasonal effect on solar distillation in the El-Oued region of south-east Algeria," International Journal of Energetica, vol. 2, no. 1, 2017.

[20] A. Khechekhouche, A. B. Kabeel, B. Benhaoua, M. E. H. Attia, and E. M. S. El-Said, "Traditional solar distiller improvement by a single external refractor under the climatic conditions of the El Oued region, Algeria," Desalination and Water Treatment, vol. 177, pp. 23-28, 2020.

[21] A. Johnson, L. Mu, Y. H. Park et al., "A thermal model for predicting the performance of a solar still with Fresnel lens," Water, vol. 11, no. 9, p. 1860, 2019.

[22] A. Khechekhouche, B. Boubaker, and Z. Driss, "Solar distillation between a simple and double-glazing," Revue de mécanique, vol. 2, 2018.

[23] M. M. Morad, H. A. M. El-Maghawry, and K. I. Wasfy, "Improving the double slope solar still performance by using flat-plate solar collector and cooling glass cover," Desalination, vol. 373, pp. 1-9, 2015.

[24] T. Prem kumar, S. Moulieswaran, and S. Pradeep, "Effect of glazing and cooling on solar waste water still," International Journal of Research and Analytical Reviews, vol. 6, no. 1, pp. 927-932, 2019.

[25] B. T. Nguyen, "Factors Affecting the Yield of Solar Distillation Systems and Measures to Improve Productivities," in Desalination and Water Treatment, IntechOpen, 2018.

[26] D. Bechki, H. Bouguettaia, J. Blanco-Galvez et al., "Effect of partial intermittent shading on the performance of a simple basin solar still in South Algeria," Desalination, vol. 260, no. 1-3, pp. 65-69, 2010.

[27] R. Cherraye, B. Bouchekima, D. Bechki, H. Bouguettaia, and A. Khechekhouche, "The effect of tilt angle on solar still productivity at different seasons in arid conditions (South Algeria)," International Journal of Ambient Energy, vol. 41, pp. 17, 2020.

[28] H. N. Panchal and P. K. Shah, "Effect of varying glass cover thickness on performance of solar still: in a winter climate conditions," International Journal of Renewable Energy Research, vol. 1, pp. 212-223, 2011.

[29] J. S. Gawande and L. B. Bhuyar, "Effect of glass cover thickness on the performance of stepped type solar still," International Journal of Innovative Science and Research Technology, vol. 1, pp. 19-26, 2013.

[30] M. K. Boodhan and I. Haraksingh, "An investigation into the effect on the productivity of cascade-type solar distillation systems with varying cover thicknesses and still orientations under tropical Caribbean climatic conditions," Desalination and Water Treatment, vol. 55, no. 12, pp. 3295-3302, 2014.

[31] R. Bakari, R. J. A. Minja, and K. N. Njau, "Effect of glass thickness on performance of flat plate solar collectors for fruits drying," Journal of Energy, vol. 2014, Article ID 247287, 8 pages, 2014.

[32] A. O. Edeoja, F. Unom, and J. A. Edeoja, "Investigation of the effect of cover thickness on the yield of a single basin solar still under Makurdi climate," International Journal of Engineering Science Invention, vol. 14, pp. 131-138, 2015.
[33] H. Panchal, "Performance investigation on variations of glass cover thickness on solar still: experimental and theoretical analysis," Technol Econ Smart Grids Sustain Energy, vol. 1, no. 1, p. 7, 2016.

[34] A. Santos and E. Hernandez, "Experimental evaluation of a single slope solar still," TECCIENCIA, vol. 12, no. 22, pp. 6371, 2017.

[35] A. T. Balewa, K. Polytechnic, and F. Polytechnic, "Effect of glass thickness on solar still performance," Journal of Engineering and Applied Science, vol. 11, pp. 49-58, 2019.

[36] A. Khechekhouche, Z. Driss, and B. Durakovic, "Effect of heat flow via glazing on the productivity of a solar still," International Journal of Energetica, vol. 4, no. 2, pp. 54-57, 2020.

[37] M. Khan and M. Mustafa, "Solar still distillate productivity enhancement by using reflector and design optimization," Innovative Energy \& Research, vol. 8, 2019.

[38] A. Khechekhouche, B. Benhaoua, A. M. Manokar, A. E. Kabeel, and R. Sathyamurthy, "Exploitation of an insulated air chamber as a glazed cover of a conventional solar still," Heat Transfer-Asian Research, vol. 48, no. 5, pp. 1563-1574, 2019.

[39] A. M. Manokar, D. P. Winston, J. D. Mondol, R. Sathyamurthy, A. E. Kabeel, and H. Panchal, "Comparative study of an inclined solar panel basin solar still in passive and active mode," Solar Energy, vol. 169, pp. 206-216, 2018.

[40] A. Khechekhouche, B. Benhaoua, M. Manokar, R. Sathyamurthy, A. E. Kabeel, and Z. Driss, "Sand dunes effect on the productivity of a single slope solar distiller," Heat and Mass Transfer, vol. 56, no. 4, pp. 1117-1126, 2020.

[41] M. M. Thalib, A. M. Manokar, F. A. Essa, N. Vasimalai, R. Sathyamurthy, and F. P. G. Marquez, "Comparative study of tubular solar stills with phase change material and nanoenhanced phase change material," Energies, vol. 13, no. 15, p. 3989, 2020.

[42] S. Nazari, M. Bahiraei, H. Moayedi, and H. Safarzadeh, "A proper model to predict energy efficiency, exergy efficiency, and water productivity of a solar still via optimized neural network," Journal of Cleaner Production, vol. 277, 2020. 